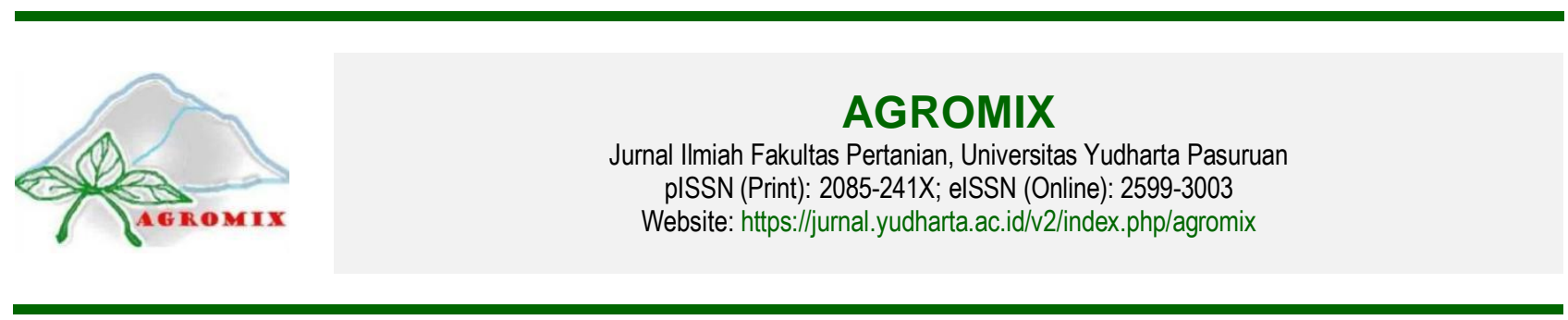

\title{
Kajian sosial ekonomi pada petani garam di wilayah Madura
}

\author{
Socio-economic studies on salt farmers in the Madura region
}

\author{
Kustiawati Ningsih ${ }^{1^{*}}$, Nur Laila ${ }^{1}$ \\ ${ }^{1}$ Fakultas Pertanian, Universitas Islam Madura, Indonesia \\ *Email korespondensi: kustiawatin@gmail.com
}

\author{
Article History \\ Received : July 3, 2021 \\ Accepted : September 15, 2021 \\ Published : September 28, 2021 \\ Keyword \\ Madura salt farmers; \\ socio-economic; range score
}

\section{ABSTRACT}

As one of the islands in Indonesia, Madura is one of the salt-producing centers in Indonesia, thus earning the nickname as the Salt Island. Therefore, almost $80 \%$ of the population in Madura have a livelihood as salt farmers and including salt farmers in Bunder Village, Pademawu District, Pamekasan Regency. However, the weak adoption power of Madura salt farmers in Bunder Village, Pademawu District, Pamekasan Regency to the new technology, namely geomembrane, has a very significant socioeconomic impact on salt farmers. So the purpose of this study was to examine the socio-economic conditions of Madura salt farmers in Bunder Village, Pademawu District, Pamekasan Regency. Data were collected through primary data (observations and interviews) and secondary data. The data obtained from the results of the study were processed using qualitative analysis (income analysis) and quantitative analysis (range score analysis of BPS welfare indicators in 2015) to ensure the socioeconomic conditions of Madura salt farmers in Bunder Village, Pademawu District, Pamekasan Regency. The results showed that (1) The average monthly income of salt farmers was IDR 1,784,416 per hectare per month (2) The average range score of Madura salt farmers based on the BPS welfare indicators in 2020 was in the poor category.

\section{Riwayat Artikel}

Dikirim : 3 Juli, 2021

Disetujui : 15 September, 2021

Diterbitkan : 28 September, 2021

\section{Kata Kunci}

Petani garam Madura; sosial ekonomi; range score

\section{ABSTRAK}

Sebagai salah satu pulau di Indonesia , Madura merupakan salah satu sentra penghasil garam di Indonesia sehingga mendapatkan julukan sebagai Pulau Garam. Oleh karena itu hampir $80 \%$ penduduk di Madura memiliki mata pencaharian sebagai petani garam dan termasuk di dalamnya petani garam di Desa Bunder, Kecamatan Pademawu, Kabupaten Pamekasan. Namun, lemahnya daya adopsi petani garam Madura di Desa Bunder, Kecamatan Pademawu, Kabupaten Pamekasan terhadap teknologi baru yaitu geomembran memberikan dampak sosial ekonomi yang sangat signifikan terhadap petani garam. Sehingga tujuan dari penelitian ini adalah untuk mengkaji kondisi sosial ekonomi petani garam Madura di Desa Bunder, Kecamatan Pademawu, Kabupaten Pamekasan. Data dikumpulkan melalui data primer (obervasi dan wawancara) dan data sekunder. Data yang diperoleh dari hasil kajian diolah dengan menggunakan analisis kualitatif (analisis pendapatan) dan analisis kuantitatif (analisis range score indikator kesejahteraan BPS Tahun 2015) untuk memastikan kondisi sosial ekonomi petani garam Madura di Desa Bunder, Kecamatan Pademawu, Kabupaten Pamekasan. Hasil penelitian menunjukkan bahwa (1) Rata-rata pendapatan petani garam per bulannya adalah $\mathrm{Rp} 1.784 .416$ per hektar per bulan (2) Rata-rata range score petani garam Madura berdasarkan indikator kesejahteraan BPS tahun 2020 berada dalam kategori kurang.

Sitasi: Ningsih, K., \& Laila, N. (2021). Kajian sosial ekonomi pada petani garam di wilayah Madura. Agromix, 12(2), 129-136. https://doi.org/10.35891/agx.v12i2.2573

\section{PENDAHULUAN}

Luas perairan Indonesia hampir dua pertiganya atau sekitar $70 \%$ memiliki potensi yang sangat bermanfaat di antaranya seperti ikan laut, rumput laut, mineral garam terlarut, mutiara, serta tambang minyak bumi. Komoditas utama perairan laut Indonesia adalah garam yang merupakan kebutuhan pokok serta dikonsumsi sehari-hari oleh masyarakat Indonesia sekitar $4 \mathrm{~kg}$ per tahun. Namun selain memiliki fungsi sebagai kebutuhan pokok sehari-hari, garam juga bisa menjadi komoditas strategis yaitu sebagai bahan baku industri (Widiarto dkk., 2013). Soesilowati dan Garam (2013) menyatakan bahwa secara garis besar penggunaan garam dibagi menjadi 3 (tiga) jenis yaitu (1) Garam untuk pengasinan dan aneka pangan (2) Garam untuk konsumsi manusia, dan (3) Garam untuk industri. Kabupaten Pamekasan merupakan salah satu sentra penghasil garam di pulau Madura bahkan nasional. Produksi garam di Pulau 
Madura sekitar $60 \%$ dihasilkan oleh para petani garam yang ada di Kabupaten Pamekasan. Total luas lahan garam yang ada di Kabupaten Pamekasan adalah $\pm 5.545 \mathrm{Ha}$ yang terbagi menjadi 2 kepemilikan yaitu lahan garam rakyat seluas $4.300 \mathrm{Ha}$ dengan kapasitas produksi garam \pm 300.000 ton/tahun dan lahan milik PT. Garam seluas $\pm 1.245 \mathrm{Ha}$ dengan kapasitas produksi garam berkisaran 60.000 ton/tahun. Abdullah dan Susandini (2018) menyatakan bahwa total produksi garam Kabupaten Pamekasan adalah \pm 360.000 ton/tahun dari total produksi garam nasional yaitu 1,2 juta ton/tahun

Salah satu desa sentra penghasil garam di Kabupaten Pamekasan adalah Desa Bunder Kecamatan Pademawu dan lokasinya berdekatan dengan lokasi produksi milik PT Garam. Sebagai perusahaan yang bergerak di bidang penggaraman, PT Garam mulai memperkenalkan teknologi produksi garam dengan menggunakan geomembran. Teknologi geomembran sebagai metode produksi baru mulai berkembang di Desa Bunder dan sebagian petani garam sudah menerapkan teknologi baru ini. Menurut Xue dkk. (2013) dan Arwiyah dkk. (2015), untuk mempercepat penguapan dan mempersingkat terjadinya kristalisasi garam maka perlu diterapkannya teknologi geomembran dari HDPE (High Density Poly Ethylene). Meningkatnya kualitas dan kuantitas produksi garam dapat diperoleh dengan menerapkan metode geomembran. Ramli (2012) menyatakan bahwa teknologi geomembran merupakan salah satu jenis material geosintetik yang berfungsi sebagai lapis kedap air yang terbuat dari bahan sintetik semacam plastik

Kondisi di lapangan menunjukkan bahwa sebagian besar masyarakat mengeluh tidak dapat memenuhi kebutuhan sehari-hari mereka, padahal mereka sudah beralih dari petani garam tradisional ke petani garam modern yang seharusnya dengan penggunaan teknologi baru (geomembran) tersebut dapat meningkatkan pendapatan petani garam.

Permasalahan utama yang dihadapi oleh petani garam di Desa Bunder Kecamatan Pademawu, Kabupaten Pamekasan adalah penggunaan teknologi dan metode produksi yang masih sederhana sehingga hal ini menyebabkan kualitas garam yang dihasilkan petani masih rendah. Saragih dkk. (2018) menyatakan bahwa untuk mengurangi permasalahan yang berkaitan dengan produksi dan kualitas garam, diperlukan suatu teknologi yang dapat, meningkatkan produksi dan kualitas garam Permasalahan lainnya adalah daya adopsi petani garam masih lemah terhadap teknologi baru, khususnya dalam menggunakan teknologi geomembran. Fenomena ini terjadi karena sebagian besar petani garam masih memiliki pola pikir yaitu produksi garam yang menggunakan cara tradisional lebih mudah karena telah dilakukan sejak lama dan turun-temurun dan apabila mereka beralih menggunakan teknologi geomembran maka biaya produksi menjadi semakin tinggi dan produksi garam yang diperoleh dengan cara cepat akan mengalami penyusutan. Perilaku petani dalam menerapkan teknologi geomembran juga tergantung dari kondisi sosial ekonomi seperti pendidikan, keanggotaan dalam kelompok tani garam, penggunaan luas lahan tambak serta tingkat pendapatan.

Berdasarkan permasalahan yang dihadapi oleh petani garam di Desa Bunder, Kecamatan Pademawu, Kabupaten Pamekasan, maka peneliti tertarik untuk meneliti tentang "Kajian Sosial Ekonomi Petani Garam Teknologi Geomembran di Desa Bunder Kecamatan Pademawu". Kajian sosial ekonomi dalam penelitian ini memiliki ruang lingkup yaitu kedudukan atau posisi seseorang dalam kelompok masyarakat yang di tentukan oleh jenis aktivitas ekonomi, pendidikan dan pendapatan rata-rata keluarga per tahun. Penelitian ini bertujuan untuk mengkaji sosial ekonomi petani garam Madura, khususnya di Desa Bunder Kecamatan Pademawu, Kabupaten Pamekasan setelah menerapkan teknologi geomembran dalam proses produksi garam.

\section{METODE}

\section{Lokasi dan waktu penelitian}

Penelitian ini di lakukan di Desa Bunder Kecamatan Pademawu Kabupaten Pamekasan, pada Tahun 2020. Lokasi penelitian di tentukan secara sengaja (purposvie) atau di tunjuk langsung dengan pertimbangan bahwa Desa Bunder Kecamatan Pademawu merupakan salah satu daerah sentra penghasil garam di Kabupaten Pamekasan dan di Desa tersebut sebagian besar petani garam sudah beralih menggunakan teknologi geomembran dalam proses produksi garam.

\section{Jenis data dan metode pengambilan data}

Penelitian ini menggunakan 2 jenis data yaitu data primer (data utama penelitian) dan data sekunder (data pendukung penelitian). Data primer diperoleh melalui observasi langsung ke lokasi penelitian dan wawancara dengan responden. Data primer meliputi identitas responden, produksi dan pendapatan responden, dan indikator tingkat kesejahteraan responden berlandaskan indikator tingkat kesejahteraan menurut Badan Pusat Statistik (2015). Data sekunder adalah data pendukung penelitian, yang diperoleh melalui tinjauan beberapa sumber kepustakaan yang berkaitan dengan tujuan penelitian. Data sekunder dalam penelitian ini meliputi monografi desa yang diterbitkan oleh Pemerintah Desa Bunder, dan hasil-hasil penelitian yang sesuai dengan tujuan penelitian. 


\section{Metode penarikan sampel}

Penarikan sampel di lakukan dengan menggunakan metode acak (simple random sampling). Populasi petani garam di Desa Bunder Kecamatan Pademawu sebanyak 57 orang, sehingga jumlah sampel diperoleh sebanyak 36 orang, dengan menggunakan rumus Slovin sebagai berikut:

$$
\mathrm{n}=\frac{N}{1+N d 2}
$$

Ketarangan :

$N=$ besar populasi 57 orang

$d=$ kesalahan yang di inginkan $10 \%(0.1)$

$\mathrm{n}=\frac{57}{1+57(0.1) 2}$

$\mathrm{n}=36$

$\mathrm{n}=36$ Petani Garam

\section{Metode analisis data}

Kajian sosial ekonomi terhadap petani garam Madura menggunakan metode analisis deskriptif analitik. Dalam penelitian ini menggunakan analisis pendapatan petani garam dan analisis tingkat kesejahteraan petani garam.

\section{Analisis pendapatan petani garam}

Soekartawi (2016) menyatakan bahwa pendapatan usahatani adalah selisih antara penerimaan dan semua biaya. Pendapatan petani garam geomembran dihitung dengan menggunakan rumus berikut ini:

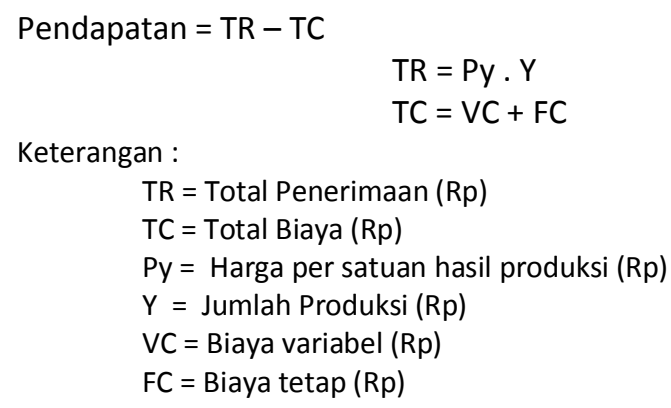

\section{Analisis tingkat kesejahteraan petani garam}

Analisis tingkat kesejahteraan petani garam diukur dengan menggunakan tujuh indikator kesejahteraan berdasarkan (Badan Pusat Statistik, 2015) yang terdiri dari 7 indikator kesejahteraan yaitu kependudukan, kesehatan dan gizi, pendidikan, ketenagakerjaan, taraf dan pola konsumsi, perumahan dan lingkungan, sosial dan lain-lain. Klasifikasi kesejahteraan yang digunakan yaitu rumah tangga sejahtera dan belum sejahtera. Dalam penelitian ini variabel pengamatan disertai dengan klasifikasi dan skor yang dapat mewakili besaran klasifikasi indikator tersebut. Skor tingkat klasifikasi pada 7 indikator kesejahteraan dihitung berdasarkan pedoman penentuan Range Score. Rumus penentuan range score adalah:

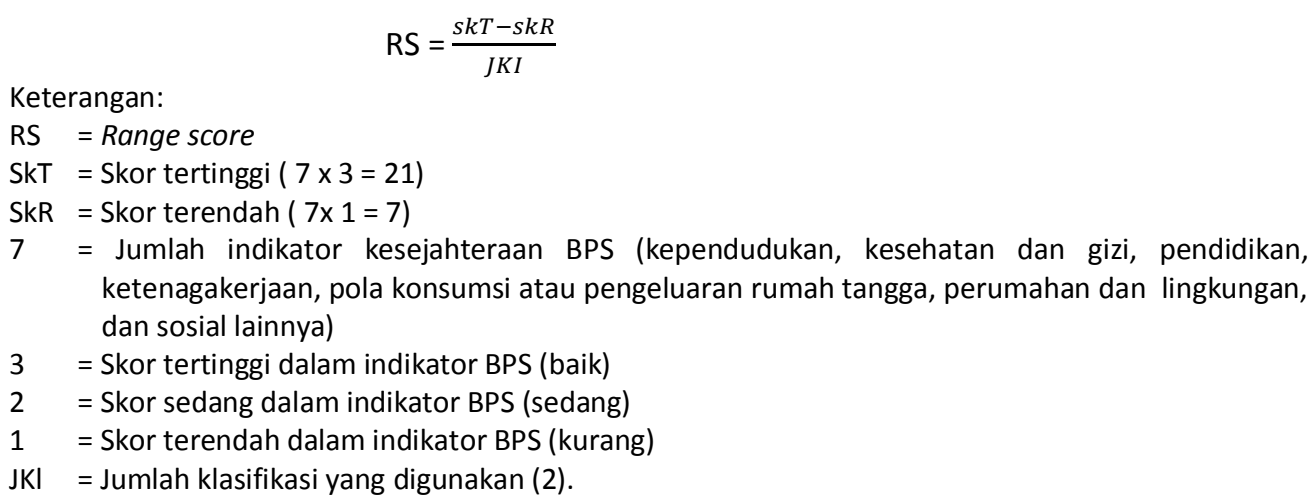

Berdasarkan rumus tersebut di atas, maka diperoleh Range score (RS) yang memiliki nilai sama dengan tujuh, sehingga dari range score yang diperoleh menggambarkan interval skor yang akan menunjukkan tingkat kesejahteraan rumah tangga petani garam. Terdapat hubungan antara interval skor dan tingkat kesejahteraan sebagai berikut: 
1) Jika skor antara 7-14 berarti rumah tangga petani belum sejahtera.

2) Jika skor antara 15-21 berarti rumah tangga petani sejahtera.

Jumlah skor diperoleh dari hasil skor indikator kesejahteraan yaitu kependudukan, kesehatan dan gizi, pendidikan, ketenagakerjaan, taraf dan pola konsumsi, perumahan dan lingkungan, sosial dan lain-lain. Berdasarkan hasil skor tersebut kemudian dapat ditentukan interval skor dari dua kategori klasifikasi yaitu rumah tangga sejahtera dan belum sejahtera.

\section{HASIL DAN PEMBAHASAN}

\section{Analisis pendapatan petani garam}

Produksi garam biasanya dilakukan pada musim kemarau yaitu antara bulan April sampai dengan bulan November. Abdullah dan Susandini (2018) menyatakan bahwa metode evaporasi murni yang digunakan dalam produksi garam sangat bergantung pada keberadaan sinar matahari dan hal ini berkaitan dengan kelembaban dan kecepatan angin. Menurut Azka dkk. (2018) dan Bramawanto dkk. (2019) kualitas air laut yang dimasukkan ke tambak garam, struktur dan morfologi tanah, topografi, sifat fisis tanah, kanal air dan bebas dari pengganggu seperti tanaman, ternak dan limbah rumah tangga sangat mempengaruhi produksi garam. Input yang digunakan dalam usahatani garam hanyalah berupa air laut saja dan tidak memerlukan input lainnya. Oleh karena itu dapat dikatakan usahatani garam adalah sebuah usaha yang unik. Pendapatan petani garam diperoleh melalui analisis pendapatan petani garam yang melakukan usahatani garam. Analisis dilakukan dengan cara mengurangkan nilai penjualan garam dengan biaya produksi pada musim 2020. Biaya produksi adalah biaya-biaya yang dikeluarkan dalam usahatani garam. Biaya tersebut terdiri dari biaya peralatan produksi, biaya garap, biaya pungut, biaya pengarungan, biaya pengangkutan dan biaya lain-lain. Tabel 1. menunjukkan biaya produksi dalam usahatani garam.

Tabel 1. Biaya produksi usahatani garam di Desa Bunder, Kecamatan Pademawu, Kabupaten Pamekasan (2020)

\begin{tabular}{|c|c|c|}
\hline No & Jenis Biaya & Jumlah Biaya (Rp) \\
\hline 1 & Biaya peralatan & 2.000 .000 \\
\hline 2 & Garap & 30.000 .000 \\
\hline 3 & Pungut & 7.000 .000 \\
\hline 4 & Pengarungan & 10.000 .000 \\
\hline 5 & Pengangkutan & 5.750 .000 \\
\hline \multirow[t]{2}{*}{6} & Biaya lain - lain & 2.800 .000 \\
\hline & Total & 57.550 .000 \\
\hline
\end{tabular}

Sumber : Data prime, diolah (2020)

Berdasarkan Tabel 1. dapat dilihat bahwa biaya terbesar dalam usahatani garam adalah biaya tenaga kerja pada saat penggarapan, persiapan sebelum panen dan pemeliharaan selama masa panen.. Biaya terbesar selanjutnya adalah biaya lain - lain yang meliputi biaya tutup gudang, biaya lepas geomembran, biaya pungut dan lainnya.

Penerimaan diperoleh dari perkalian antara jumlah produksi garam per hektar per musim dengan harga yang diterima per hektar per musim. Berdasarkan data yang diperoleh, usaha garam pada musim 2020 diperoleh rata-rata produksi per hektar per musim 40,34 ton pada luas lahan rata-rata 1,58 ha. Kondisi ini sangat memprihatinkan karena harga garam pada saat dilakukan penelitian menurun yang awalnya 20.000 per ton menjadi 17.000 per ton nya. Hal ini didukung oleh penelitian (Rahman dkk., 2014) yang menyatakan bahwa faktor yang paling mempengaruhi terhadap produktivitas usaha petani garam adalah mutu bahan baku air laut dan kesiapan lahan petani garam dalam memproduksi garam yang tepat waktu, yaitu pada saat di awal musim garam.

Para petani penggarap dan pemilik lahan memperoleh keuntungan yang sedikit dari tahun-tahun sebelumnya. Petani penggarap memperoleh bagian 30\% dari jumlah produksi yang diperoleh dan $70 \%$ sisanya diberikan kepada pemilik tanah. Kondisi ini berlaku apabila semua alat-alat produksi seperti kincir, gledek dan sebagainya berasal dari pemilik tanah. Sementara jika alat-alat produksi berasal dari petani penggarap atau mantong maka pembagiannya adalah 50\% untuk petani penggarap dan 50\% untuk pemilik tanah. Namun pada umumnya yang berlaku di lapangan adalah petani penggarap hanya mengerjakan saja dan semua alat-alat produksi berasal dari pemilik tanah. Dengan demikian maka data diproksikan bahwa pendapatan petani penggarap tersebut memperoleh $30 \%$ dari jumlah tersebut sehingga rata-rata pendapatan petani garam per bulannya adalah Rp 1.784,416 per hektar per bulan atau sekitar Rp 59.480,53 per hari.

Bank Dunia menyatakan bahwa kemiskinan adalah penduduk yang berpenghasilan di bawah 2 dollar per hari, sehingga berdasarkan kriteria Bank Dunia tersebut, maka petani garam Madura perlu mendapat perhatian yang serius. Besaran pendapatan yang diperoleh yaitu sesuai dengan sistem bagi hasil dengan pemilik lahan. Karena pada setiap bulannya penghasilan petani selalu tidak sama diakibatkan kondisi cuaca. Menurut Pri Haryatno (2013) permasalahan lingkungan utama yang dihadapi oleh petani garam adalah perubahan cuaca yang tidak menentu sehingga petani garam harus mampu beradaptasi terhadap cuaca yang tidak menentu ini karena segala aktivitas 
petani garam sangat bergantung pada cuaca. Hasil penelitian Yaqin (2017) menunjukkan bahwa rata-rata pendapatan petani garam geomembran sebesar Rp. 1.732,222 dengan luas lahan kurang dari 2 ha. Hasil penelitian pendukung lainnya adalah hasil penelitian Zakki dan Sayyida (2016) yang menunjukkan bahwa terdapat 4 faktor yang mempengaruhi tingkat dan pendapatan petani garam yaitu jenis usaha, modal, kepemilikan lahan dan pendapatan.

\section{Analisis tingkat kesejahteraan petani garam}

Analisis tingkat kesejahteraan petani garam didasarkan pada beberapa indikator tingkat kesejahteraan dari Badan Pusat Statistik (2015). Adapun hasil analisis beberapa indikator tingkat kesejahteraan petani garam adalah sebagai berikut :

\section{Kependudukan}

Gambaran keluarga petani garam mengenai jumlah anggota keluarga dan beban tanggungan dalam keluarga dapat diketahui dari indikator kependudukan Kondisi pengeluaran keluarga dalam memenuhi kebutuhan sehari- hari dicerminkan dari jumlah anggota keluarga. Hasil analisis range score untuk paramater kependudukan dapat dilihat pada Tabel 2. berikut :

Tabel 2. Range score indikator kependudukan petani garam Madura

\begin{tabular}{cccc}
\hline Kategori & Interval skor & Jumlah & Persentase \\
\hline Baik & $12-15$ & 28 & 77,8 \\
Cukup & $8-11$ & 5 & 13,9 \\
Kurang & $4-7$ & 3 & 8.3 \\
\hline Total & & 36 & 100 \\
\hline
\end{tabular}

Sumber : Data primer, diolah (2020)

Tabel 2. di atas menyajikan range score indikator kependudukan petani garam, terlihat bahwa perolehan skor untuk indikator kependudukan pada petani garam berada dalam kategori baik yaitu sebesar 77,8 \% . Kemudian kategori cukup 13,9 \% dan dalam kategori kurang 8,3\%. Hal ini menggambarkan tentang kualitas dan kuantitas petani tidak sama. Hal ini didukung oleh hasil penelitian Sabara dkk. (2016) yang menyatakan bahwa faktor keluarga merupakan salah satu faktor yang mempengaruhi strategi bertahan hidup dari petani garam, sehingga petani garam lebih termotivasi untuk meningkatkan pendapatan dan kesejahteraan keluarga mereka.

\section{Kesehatan dan gizi}

Salah satu indikator yang dapat digunakan untuk melihat tingkat kesejahteraan adalah kesehatan. Misalnya, tentang ada tidaknya keluhan tentang kesehatan, pengetahuan tentang pentingnya gizi dalam keluarga petani serta akses kepada fasilitas kesehatan yang tersedia.

Tabel 3. Range score indikator kesehatan dan gizi petani garam Madura

\begin{tabular}{cccc}
\hline Kategori & Interval skor & Jumlah & Persentase \\
\hline Baik & $12-15$ & 1 & 2,8 \\
Cukup & $8-11$ & 16 & 44,5 \\
Kurang & $4-7$ & 19 & 52,8 \\
\hline Total & & 36 & 100 \\
\hline
\end{tabular}

Sumber : Data primer, diolah (2020)

Tabel 3. menunjukkan bahwa 2,8 \% petani garam berada pada kategori baik, kemudian 44,5 \% kategori cukup dan $52,8 \%$ dalam kategori kurang. Keluarga petani masih ada keluhan tentang kesehatan. Tenaga kesehatan yang digunakan keluarga adalah bidan. Sarana kesehatan rata-rata adalah puskesmas dan tempat keluarga petani memperoleh obat adalah obat warung. Menurut Fitriah dkk. (2019) petani garam dapat mengalami involuntary dahydration yang disebabkan oleh penggunaan APD yang buruk dan tidak lengkap yaitu seperti pakaian lengan panjang, topi, sarung tangan, masker dan sepatu.

\section{Pendidikan}

Indikator kesejahteraan yang dapat memberikan gambaran tentang bagaimana keluarga terbebas dari buta huruf dan melaksanakan wajib belajar 9 tahun adalah indikator pendidikan. Kondisi anggota keluarga yang berusia 10 tahun ke atas dalam membaca dan menulis menggambarkan hal ini. Kemampuan mengadopsi teknologi sangat dipengaruhi oleh tingkat pendidikan sehingga dapat meningkatkan pendapatan keluarga petani. Bagi petani garam Madura, pendidikan bukan hal yang sangat penting karena menurut mereka memenuhi kebutuhan pokok menjadi hal yang utama dan penting dalam kehidupan petani. Tingkat kemampuan membaca dan menulis untuk usia 10 ke atas umumnya sudah cukup baik meskipun ada sebagian petani ada yang belum bisa membaca dan menulis karena tingkat pendidikan yang rendah. Karena keterbatasan dana petani tidak bisa melanjutkan pendidikan putra-putrinya ke jenjang perguruan tinggi. Sehingga setelah tamat sekolah mereka lebih memilih bekerja ke luar kota maupun ke luar negeri menjadi TKI. 
Tabel 4. Range score indikator pendidikan petani garam Madura

\begin{tabular}{cccc}
\hline Kategori & Interval skor & Jumlah & Persentase \\
\hline Baik & $18-21$ & 1 & 2,8 \\
Cukup & $14-17$ & 10 & 27,8 \\
Kurang & $10-13$ & 25 & 69,5 \\
\hline Total & & 36 & 100
\end{tabular}

Sumber : Data primer, diolah (2020)

Pada Tabel 4. di atas, dapat terlihat bahwa range score untuk indikator pendidikan menunjukkan bahwa 2,8\% dalam kategori baik, 27,8\% ada dalam kategori cukup, dan 69,5\% dalam kategori kurang. Data tersebut menunjukkan pendidikan keluarga petani responden masih kurang sehingga tidak dapat meningkatkan pendapatan petani. Hal ini didukung oleh hasil penelitian Hotimah dan Singgih (2019) yang menyatakan bahwa rendahnya pendidikan formal oleh petani garam menyebabkan rendahnya pendapatan yang diperoleh. Sehingga diperlukan strategi, salah satunya adalah menyimpan garam untuk dijual pada musim penghujan karena pada saat musim penghujan, garam menjadi sulit sehingga harganya akan lebih tinggi dari sebelumnya.

\section{Ketenagakerjaan}

Gambaran keluarga petani mengenai jumlah anggota keluarga yang bekerja dan lama waktu bekerja dapat diketahui dari indikator ketenagakerjaan. Kondisi pendapatan yang akan diterima guna memenuhi kebutuhan pengeluaran rumah tangga sehari-hari dicerminkan dari Jumlah anggota keluarga yang bekerja.

Tabel 5. Range score indikator ketenagakerjaan petani garam Madura

\begin{tabular}{cccc}
\hline Kategori & Interval skor & Jumlah & Persentase \\
\hline Baik & $12-15$ & 1 & 2,8 \\
Cukup & $8-11$ & 13 & 36,2 \\
Kurang & $4-7$ & 22 & 61,2 \\
\hline Total & & 36 & 100 \\
\hline
\end{tabular}

Sumber : Data primer, diolah (2020)

Berdasarkan Tabel 5. terlihat bahwa kondisi ketenagakerjaan petani responden 2,8\% pada kategori baik , 36,2\% dalam kategori cukup dan $61,2 \%$ dalam kategori kurang. Hal ini di sebabkan lantaran petani responden tidak memiliki pekerjaan sampingan dan hanya mengandalkan usahataninya. Jumlah jam untuk melakukan pekerjaan $>30$ jam per minggu. Mereka berpendapat rata- rata pekerjaan membutuhkan keahlian khusus. Upah yang di terima tidak cukup untuk memenuhi kebutuhan hidup. Menurut Sabara dkk. (2016) salah satu strategi bertahan hidup petani garam adalah melakukan pekerjaan lain. Hal ini tentu akan sangat berguna untuk menutupi pekerjaan bertani garam yang sepenuhnya bergantung pada faktor cuaca. Pekerjaan lain yang dapat dilakukan oleh petani garam di antaranya peternak, perancang dan petani sawah.

\section{Taraf dan pola konsumsi}

Indikator yang memberikan gambaran tentang pola pengeluaran keluarga adalah indikator konsumsi. Pengeluaran merupakan data sebenarnya untuk melihat seluruh pendapatan yang diperoleh keluarga petani.

Tabel 6. Range score indikator taraf dan pola konsumsi petani garam Madura

\begin{tabular}{cccc}
\hline Kategori & Interval skor & Jumlah & Persentase \\
\hline Baik & $10-12$ & 0 & 0 \\
Cukup & $7-9$ & 10 & 27,8 \\
Kurang & $4-6$ & 26 & 72,2 \\
\hline Total & & 36 & 100 \\
\hline
\end{tabular}

Sumber : Data Primer, diolah (2020)

Pada Tabel 6. di atas dapat terlihat bahwa konsumsi keluarga petani ada $27,8 \%$ dalam kategori cukup dan $72,2 \%$ dalam kategori kurang. Keluarga petani tidak menyisakan dana untuk kebutuhan sandang dan perumahan karena pendapatan yang di peroleh hanya cukup untuk memenuhi konsumsi pangan dalam satu bulan. Susandini dan Jannah (2021) menyatakan bahwa pola konsumsi petani garam di Madura dikelompokkan menjadi dua yaitu pengeluaran konsumsi (makanan dan pakaian), pengeluaran bukan makanan antara lain biaya pendidikan, listrik, PDAM, kesehatan, komunikasi, transportasi, kredit dan lainnya dan faktor sosial budaya merupakan faktor yang paling berpengaruh terhadap besarnya konsumsi petani garam.

\section{Perumahan dan lingkungan}

Kondisi perumahan petani responden dapat dilihat dari jenis WC yang di gunakan. Umumnya petani responden masih menggunakan WC cemplung. Tempat pembuangan sampah sebagian besar masih berupa pekarangan. Tingkat 
pendapatan keluarga dicerminkan dari kualitas perumahan dan hal ini mempengaruhi kesejahteraan penghuninya. Semakin baik kualitas perumahan semakin tinggi kesejahteraannya.

Tabel 7. Range score indikator perumahan dan lingkungan petani garam Madura

\begin{tabular}{cccc}
\hline Kategori & Interval skor & Jumlah & Persentase \\
\hline Baik & $18-21$ & 0 & 0 \\
Cukup & $14-17$ & 9 & 25 \\
Kurang & $10-13$ & 27 & 75 \\
\hline Total & & 36 & 100 \\
\hline
\end{tabular}

Sumber : Data primer, diolah (2020)

Tabel 7. menunjukkan bahwa $25 \%$ ada dalam kategori cukup dan $75 \%$ berada dalam kategori kurang. Skor untuk indikator perumahan petani responden masih dalam kategori kurang. Hal ini didukung oleh hasil penelitian Winarno (2018) yang menyatakan bahwa rumah petani garam pada umumnya masih sederhana dengan dinding bilik. Sementara itu mobilitas sosial (perubahan status sosial) seseorang untuk usia dewasa dan tua tidak banyak mengalami perubahan, tapi untuk umur remaja dan anak-anak banyak mengalami perubahan, walaupun secara khusus tidak terdapat catatan administrasinya di kelurahan.

\section{Sosial dan lain-lain}

Indikator sosial dan lain-lain dapat di lihat dari kemudahan dalam akses berwisata dan kemampuan dalam menggunakan teknologi.

Tabel 8. Range score indikator sosial dan lain-lain petani garam Madura

\begin{tabular}{cccc}
\hline Kategori & Interval skor & Jumlah & Persentase \\
\hline Baik & $10-12$ & 0 & 0 \\
Cukup & $7-9$ & 1 & 2,8 \\
Kurang & $4-6$ & 35 & 97,2 \\
\hline Total & & 36 & 100
\end{tabular}

Sumber : Data primer, diolah (2020)

Tabel 8. menunjukkan bahwa 2,8\% petani garam Madura berada pada kategori cukup dan 97,2\% ada pada kategori kurang. Hal ini menunjukkan bahwa petani responden tidak mampu dalam penggunaan teknologi, mereka masih menggunakan telepon seluler biasa dalam berkomunikasi jarak jauh, fasilitas olahraga tidak tersedia dan tempat wisata masih kurang tersedia di daerah penelitian sehingga banyak masyarakat yang jarang meluangkan waktu untuk berwisata. Menurut Donggobolo dkk. (2021) kemampuan petani garam dalam penggunaan teknologi merupakan salah satu resiliensi capacity of learning, dimana petani garam memiliki resiliensi capacity of learning masih berada dalam kategori rendah. Hal ini menunjukkan rendahnya partisipasi dan keaktifan petani garam dalam mengikuti kegiatan pelatihan, pencarian informasi dan kemauan menerapkan hal baru dalam usaha yang digeluti. Beberapa penyuluhan dilakukan dinas terkait seperti pelatihan peningkatan kualitas garam menggunakan geoisolator, akan tetapi jumlah petani garam yang hadir sangat sedikit. Hal tersebut menyebabkan kurang berkembangnya usaha yang dilakukan, karena minimnya inovasi dalam menjalankan peningkatan nafkah rumah tangga.

\section{KESIMPULAN}

Kajian sosial ekonomi terhadap petani garam Madura di Desa Bunder Kecamatan Pademawu Kabupaten Pamekasan menunjukkan bahwa dari hasil analisis pendapatan petani garam menunjukkan bahwa rata-rata pendapatan petani garam per bulannya adalah Rp 1.784.416 per hektar per bulan. Sementara itu, berdasarkan hasil analisis tingkat kesejahteraan petani garam berdasarkan 7 indikator tingkat kesejahteraan Badan Pusat Statistik Tahun 2020 menunjukkan bahwa (1) range score indikator kependudukan petani garam Madura berada dalam kategori baik yaitu sebesar 77,8 \%, (2) range score indikator Kesehatan dan Gizi petani garam Madura sebesar 52,8 \% berada dalam kategori kurang. Hal ini disebabkan mereka belum memiliki jaminan kesehatan yang memadai. Hal ini didukung dengan kondisi di lapangan yang menunjukkan bahwa ketika petani garam atau keluarga mereka sakit, mereka hanya mengkonsumsi obat yang dijual di pasaran, (3) ) range score indikator pendidikan sebesar 69,5\% petani garam Madura berada dalam kategori kurang, (4) range score indikator ketenagakerjaan petani garam Madura sebesar $61,2 \%$ berada dalam kategori kurang, (5) range score indikator taraf dan pola konsumsi petani garam Madura sebesar $72,2 \%$ berada dalam kategori kurang, (6) range score indikator perumahan dan lingkungan petani garam Madura sebesar $75 \%$ berada dalam kategori kurang, dan (6) range score indikator sosial dan lain-lain petani garam Madura sebesar $97,2 \%$ dalam kategori kurang.

Berdasarkan hasil penelitian di atas, maka peneliti mengajukan beberapa saran di antaranya (1) Pemerintah seharusnya dapat memberikan perhatian lebih terhadap kesejahteraan petani garam dengan memberikan bantuan modal serta memberikan penyuluhan dan keterampilan kepada petani garam agar dapat lebih mengembangkan diri 
dan usahanya menuju kondisi sosial ekonomi yang lebih baik, (2) Petani garam diharapkan lebih kreatif dalam mengembangkan pekerjaan sampingan sehingga bisa lebih menguntungkan dan dapat membantu menambah pendapatan keluarga serta dapat meningkatkan kondisi sosial ekonomi ke arah yang lebih baik lagi.

\section{DAFTAR PUSTAKA}

Abdullah, A., Z., \& Susandini, A. (2018). Media produksi (geomembrane) dapat meningkatkan kualitas dan harga jual garam (study kasus: ladang garam milik rakyat di wilayah Madura). Eco-Entrepreneurship, 3(2), 21-36.

Arwiyah, Zainuri, M. dan, \& Efendy, M. (2015). Studi kandungan $\mathrm{NaCl}$ di dalam air baku dan garam yang dihasilkan serta produktivitas lahan garam menggunakan meja garam yang berbeda. Jurnal Kelautan: Indonesian Journal of Marine Science and Technology, 8(1), 1-9.

Azka, A. B. F., Santriadi, M. T., \& Kholis, M. N. (2018). Analisis strategi pengembangan usaha garam fortifikasi kelor di Kabupaten Sampang. Agroindustrial Technology Journal, 02(01), 91-97.

Badan Pusat Statistik. (2015). Indikator kesejahteraan rakyat 2015. Cerebrovascular Diseases, 170-175.

Bramawanto, R., Triwibowo, H., \& Abida, R. F. (2019). Pemanfaatan teknologi mikrokontroler untuk pengukuran evaporasi suhu udara dan air pada produksi garam skala laboratorium. Jurnal Kelautan Nasional, 14(2), $155-164$.

Donggobolo, D., Woha, K., \& Bima, K. (2021). Resiliensi dan adaptasi petani garam akibat perubahan iklim di Desa Donggobolo, Kecamatan Woha, Kabupaten Bima. Jurnal Pengelolaan Lingkungan Berkelanjutan, 5(1), 604-618.

Fitriah, N., Setyawan S, H., Adi, M. S., \& Udiyono, A. (2019). Faktor risiko kejadian dehidrasi pada petani garam di Kecamatan Kaliori, Kabupaten Rembang. Jurnal Epidemiologi Kesehatan Indonesia, 2(2), 49-54. https://doi.org/10.7454/epidkes.v2i2.1843

Hotimah, K., \& Singgih, D. S. (2019). Perwaris budaya kemiskinan dalam kehidupan petani garam (studi pada kelompok petani garam di Desa Lembung, Kec. Galis, Kab. Pamekasan [Desertasi]. Universitas Airlanggal.

Pri Haryatno, D. (2013). Kajian strategi adaptasi budaya petani garam. KOMUNITAS: International Journal of Indonesian Society and Culture, 4(2), 191-199. https://doi.org/10.15294/komunitas.v4i2.2414

Rahman, A., Raharja, S., \& Kadarisman, D. (2014). Evaluasi kinerja usaha petani garam rakyat di Kabupaten Bima, Nusa Tenggara Barat. MANAJEMEN IKM: Jurnal Manajemen Pengembangan Industri Kecil Menengah, 9(1), $106-118$. https://doi.org/10.29244/mikm.9.1.106-118

Ramli, R. (2012). Beberapa faktor sosial ekonomi penyebab tidak tuntasnya penerapan inovasi teknologi oleh petani tanaman pangan di Kalimantan Tengah. Petani dan Pembangunan Pertanian, 1, 86-93.

Sabara, M. R., Safrida, S., \& Ismayani, I. (2016). Strategi bertahan hidup (life survival) petani garam di Desa Tanoh Anoe Kecamatan Jangka Kabupaten Bireuen. Jurnal Ilmiah Mahasiswa Pertanian Unsyiah, 1(1), 353-368.

Saragih (2018). Pendapatan petambak dan faktor-faktor yang mempengaruhi produksi garam (Desa Muara Baru, Cilamaya Wetan, Karawang) [Tesis]. Institut Pertanian Bogor.

Zakki, N., \& Sayyida, S. (2016). Faktor-faktor yang mempengaruhi pendapatan dan kesejahteraan petani garam rakyat kawasan pesisir Kalianget. PERFORMANCE: Jurnal Bisnis \& Akuntansi, 6(1), 66-85.

Soekartawi. (2016). Agribisnis: teori dan aplikasinya (Edisi 1). Rajawali Pers.

Soesilowati, E., \& Garam, P. (2013). Penguatan industri garam nasional melalui perbaikan teknologi budidaya dan diversifikasi produk. Sainteknol: Jurnal Sains dan Teknologi, 11(2), $129-142$. https://doi.org/10.15294/sainteknol.v11i2.5572

Susandini, A., \& Jannah, M. (2021). Tingkat pendapatan, pola konsumsi, dan pola menabung petani garam dalam personal finance. PERFORMANCE: Jurnal Bisnis \& Akuntansi, 11(1), 11-27. https://doi.org/10.24929/feb.v11i1.1321

Widiarto, S. B., Hubeis, M., \& Sumantadinata, K. (2013). Efektivitas program pemberdayaan usaha garam rakyat di Desa Losarang, Indramayu. MANAJEMEN IKM: Jurnal Manajemen Pengembangan Industri Kecil Menengah, 8(2), 144-154. https://doi.org/10.29244/mikm.8.2.144-154

Winarno. (2018). Kajian tentang garam tradisional dan kondisi sosial, ekonomi, dan demografis petani garam di Desa Pliwetan Kecamatan Palang Kabupaten Tuban Provinsi Jawa Timur. Jurnal Geografi Edukasi dan Lingkungan (JGEL), 1(2), 99-108.

Xue, Q., Zhang, Q., Li, Z.-Z., \& Xiao, K. (2013). The tension and puncture properties of HDPE geomembrane under the corrosion of leachate. Materials, 6(9), 4109-4121. https://doi.org/10.3390/ma6094109

Yaqin, A. (2017). Karakteristik petani dan kelayakan finansial usahatani garam secara tradisional dan teknologi geomembran (studi kasus di Desa Pangarengan Kecamatan Pangarengan Kabupaten Sampang ). Jurnal Pamator, 10(1), 54-60. 